\title{
ENABLING LIMINALITY PROPHETIC WITNESS TO XENOPHOBIA: PROPOSING A MISSIOLOGICAL SPIRIT RESPONSE FOR THE CHURCH IN SOUTH AFRICA
}

Author:

Chammah J Kaunda (PhD) ${ }^{1}$

\section{Affiliation:}

${ }^{1}$ Postdoctoral Research Fellow in the Department of Christian Spirituality, University of South Africa

\section{Correspondence to:}

Chammah J Kaunda

\section{Postal Address:}

Unisa, P.O. Box 392

Pretoria, 0003

South Africa

Email:

pastorchammah@gmail.com

Dates:

15 August 2016

\section{How to cite this article:}

Kaunda, CJ, 2016. "Enabling Liminality Prophetic Witness to Xenophobia: Proposing a Missiological Spirit Response for the Church in South Africa". KOERS - Bulletin for Christian Scholarship, 81(1). Available at: http://dx.doi.org/10.19108/ KOERS.81.1.2217

\section{Copyright:}

(c) 2015. The Author(s).

Published under the Creative Commons Atribution License.
Missiological Spirit is a multidisciplinary approach to ecclesiology grounded in an understanding that all human knowledge, including secular disciplines, holds a degree of redemptive possibility because the Spirit of truth is actively engaged in every dimension of human existence. Particularly in this article, the approach intersects with anthropology, sociology, theology and ritual studies to explicate how these disciplines can interact to transform the Church in South Africa through reconceptualising some of the key Christian doctrines in the light of liminality theory. Through a case study of 2015 xenophobic attacks in South Africa that exemplifies the affinity between public speech and public violence, the article shows how a Missiological Spirit framework can inspire and empower South African Christians to respond adequately to the plague of xenophobia through consciousness-raising as prophetic resistance to violence.

Keywords: Public Speech, Missiological Spirit, South Africa, Xenophobia, liminality, Kingdom of God, Eucharist

Die Missiologiese Gees is ' $n$ multidissiplinêre benadering tot die ekklesiologie wat gegrond is die begrip dat alles menslike kennis, insluitende sekulêre disciplines, 'n mate van verlossende moontlikheid in hou, omdat die Gees vandie waarheid aktief betrokke is in elke dimensie van die menslike gees. In hierdie artikel veral kruis die gegewe met antropologie, teologie en studies van ritueel om aan te dui hoe hierdie dissiplines in interaksie kan tree om die Kerk in Suid-Afrika te transformer deur ' $n$ herkonseptualisering van sekere sleuteldoktrines van die Christendom in die lig van die teorie van liminaliteit. Deur 'n gevallestudie van die 2015 xenofobiese aanvalle in SuidAfrika wat die affiniteit van openbare redevoering en openbare geweld uitspel, toon die artikel aan hoe ' $n$ Missiologiese Geesraamwerk Suid-Afrikaanse Christene kan inspirer en versterk om toepaslik te reageer op die plaag van xenofobie deur bewusmaking as profetiese teenvoeter teen geweld.

Sleutelwoorde: Openbare redevoering, Missiologiese Gees, Suid-Afrika, xenofobie, liminaliteit, God se koninkryk, Eucharist 


\section{INTRODUCTION}

In April 2015, Mozambique, Emmanuel Sithole was beaten and stabbed in the heart with a knife by four men. The journalist who witnessed the attacked rushed him to hospital but unfortunately he died on arrival. Graphic images of this brutal murder shook the nation that was recovering from an even deadlier wave of xenophobic attacks on African foreign nationals in 2008 in which 62 people were killed and thousands fled for their lives. The recent incident claimed the lives of at least seven people. In an effort to curb violence, soldiers were deployed to the most dangerous townships such as Alexandra in Johannesburg. Thousands of fearful foreigners, mostly from Malawi, Mozambique and Zimbabwe, sought refuge in makeshift camps and churches and others chose to be repatriated. Jean Pierre Misago, a researcher at the African Centre for Migration and Society, based at the University of the Witwatersrand in Johannesburg, estimates that about 350 African foreigner nationals have been killed in xenophobic attacks since 2008 (cited in Baker 2015).

This story above encapsulates the sad fact that xenophobial has become a Missiological challenge for the Church in South Africa. In actual fact, some of the perpetrators of xenophobia are members of churches and most xenophobia victims look to the Church for safety and practical assistance in the aftermath of attacks (Phakathi 2010).2 The abiding nature of xenophobic attacks within South Africa poses deeply troubling Missiological questions: To what extent do public speeches3 contribute to xenophobic attacks in South Africa? How can a Missiological Spirit help the Church in South Africa to discern xenophobia as a Missiological challenge that must become one of the priorities on the missional agenda of the Church? How can a Missiological Spirit framework enable the Church in South Africa to reconceptualise the message of the kingdom of God and the Eucharist encounter as liminal tools for prophetic witness to xenophobia in South Africa?

The main intention of this study is to show the ways in which the Missiological Spirit can enable churches in South Africa to respond appropriately to the logic and pervasiveness of

$\overline{1}$ The term xenophobia in this study encompasses such notions as anti-African foreigner nationals and afrophobia.

In "The response of churches to the May 2008 xenophobic violence," Sizwe Phakathi narrates the testimonies from 21 churches that assisted the victims of violence.

In this article, unless specified otherwise, public speech is defined as language used with the intention to instigate violence implicitly or explicitly uttered or remarked to any audience either through media or public gatherings. It refers more specifically to public speeches from authoritative speakers, endowed with specific socio-political authority which explicitly or implicitly mediate and justify violence ideologically. Slavoj Žižek (2009) and Sabelo J. NdlovuGatsheni (2012) refer to the violence embedded in the public speech (words and language) as "symbolic". This violence "exist[s] like the dark matter of physics, and is the motive force of" (Ndlovu-Gatsheni 2012:421) "what otherwise seems to be 'irrational' explosions of subjective violence" (Žižek 2009:2). xenophobic violence embedded in the language frequently used in public spaces/spheres in the country. The concept of "public sphere" refers to a set of physical or mediated spaces where people can gather and share information, debate opinions, and tease out their political interests and social needs with other participants" (Squires 2002:448). The public spaces are never neutral but highly contested and political in nature. I use 2015 xenophobic attacks in South Africa as a case study to show how public speech by those in socio-political authority can easily be interlinked with xenophobic violence when spoken in the public context of economic frustration, exploitation and political marginalisation. I will finally demonstrate how South African churches can respond missiologically to xenophobia through consciousness-raising of believers as a resistant force against toxic public speeches.

\section{THE MISSIOLOGICAL SPIRIT APPROACH}

The 10th Assembly of World Council of Churches (hereafter the WCC) Affirmation on Mission and Evangelism argues "that the purpose of God's mission is the fullness of life (John 10:10) and that this is the criterion for discernment in mission" (Keum 2013:37, italics as found). It further argues that "The universality of the Spirit's economy in creation and the particularity of the Spirit's work in redemption have to be understood together as the mission of the Spirit..." (A New WCC Affirmation on Mission and Evangelism, 2012:254). The Missiological Spirit emphasizes the full dependence of Pneumatology on Christology. The Holy Spirit is seen as the continuing presence of Christ in the world. The Spirit witnesses to the Missio Christi through empowering the Church as Christ's agent to participate in the task of mission in the world. The emphasis is on the intersectionality of pneumatology and missiology within the milieu of violence and xenophobia. In this context, the Missiological Spirit calls the Church to a missional engagement informed by a shalomic and transformational encounter with the world. The Spirit empowers the Church to be Christ's witness to violence and xenophobia.

In the context of xenophobia, the task of the Missiological Spirit is to enable the Church in South Africa to discern the activities of the Spirit of God, particularly in terms of the liberation of the oppressed from inner violence and self-oppression, economic exploitation and political marginalisation in order to bring about healing, reconciliation and restoration of human beings and humanisation of the whole creation. The Church is called to re-examine missiologically its social constitution and realign it with the prevalent missional challenges through the mediation of the Holy Spirit. This means that the Church cannot adequately engage the world in and around itself without first reconstructing or reinterpreting some "fundamental symbols of its faith in light of the contemporary" challenges such as xenophobia (Peters 2000:392). Ted Peters (2000:392) further argues that "this contemporary context is feeling the impact of an emerging post-modern mind accompanied by a global future consciousness - the consciousness of a potential avalanche of disasters about to thunder down upon us. We need the faith that can face the future". The Spirit of God is the enabling Spirit that empowers the Church to rethink its doctrines in the light 
of present circumstances. This was evidenced at the Council of Jerusalem that gathered to deal with the missiological issue of circumcision and salvation (Acts 15). The reinterpretation of the doctrine of salvation within the context of gentiles was attributed to cooperation with the Holy Spirit - "it seemed good to the Holy Spirit and to us" (Acts 15:28).

The mission of God originates in the heart of an intrinsically reconciled, relational, and shalomic Triune God (Missio Trinitatis) as an overflow of healing, reconciliation, unconditional love and abundant life to all humanity and creation as antidote against violence and injustice. Andrew Kirk (2000: 28) in his What is Mission?, writes that "the mission of God flows directly from the nature of who God is... God's intention for the world is that in every respect it should show forth the way he is - love, community, equality, diversity, mercy, compassion and justice". This resonates with David Bosch's (1991:10) earlier assertion that the mission is an attribute of God. This means that engaging in mission is "participation in God's existence in the world". Jooseop Keum (2013:4) writes that "[t]he Church is commissioned to celebrate life through resisting and transforming all life destroying forces, in the power of the Holy Spirit". Amos Yong (2014: 47, 48) stresses that the Missiological Spirit brings "anticipation of the kingdom of God" by enabling the community of faith become fully "immersion into the liberating and reconciling work of the spirit of God in all spheres of life." The Missiological Spirit as missio Spiritus encompasses the Spirit's presence, redemptive and humanization activities in human spheres of culture, economics, politics, and socio-religious life.

Missio Spiritus enables the Church to recognise that the mission of Jesus on earth was epitomised through his violent death on the cross which uncovered once and for all the logic of mimetic violence inherent in public (hate) speech. Jesus was publicly accused of blasphemy for claiming to be the Son of God, the Messiah. The religious leaders of the day managed to sow a seed of discord and hatred against Jesus in the Jewish community. The charges brought against him before Pilate were very different from the charges in the religious trial. Before Pilate, Jesus was accused of inciting people to riot, encouraging them not to pay taxes, and claiming to be King (Luke 23). The Jewish hatred of Jesus had become so deeply entrenched that when Pilate offered the prisoner Barabbas to be crucified and Jesus released, they protested by calling for Barabbas to be released and Jesus to be crucified - this is "Jesusophobia". This also demonstrates that the public execution of Jesus was intertwined with the logic of hate speech that was constantly uttered against him by religious leaders who perceived him as a threat to their corrupt religious endeavours. By refusing to engage in the vengeful cycle of violence, Jesus critiqued the language of violence promoted through religious and political structures by which public violence is fomented. His death shows that violence can never be an instrument to bring about socio-political and economic transformation. The Holy Spirit is the power of Jesus to bear prophetic witness not just to his death but to human violence as futile means to bring about transformation.
The Holy Spirit is a missio Trinitatis Spirit and witnesses to the paradox of Christ's resistance to violence paradoxically dying a violent death on the cross in order to reconcile the world to God. The Spirit of God resists violence and destruction of life. In his The Spirit of Life, Jürgen Moltman (1992: xi) argues that the efficacy of the Spirit is universal "and ministers to life and resists its destruction." Yong (2014:230) argues that the Missiological Spirit "does not rely on Christians having or exercising political authority but on their capacity to promote the healing reconciliation essential to a peaceful, just, and beautiful world order". It requires of believers to stand firm in the face of violence and death as a radical affirmation of life. It is through this radical affirmation of life that the Church experiences and participates in the life of the Holy Spirit in the world. In other words, the Church's missional response to violence and injustice is only effective when it "is informed by pneumatological intuitions" (Yong 2014:225). In this way, the Spirit of God inspires and empowers the Church to witness to violence and injustice in the world through prophetical resistance. Missio Spiritus as prophetic resistance means that the Church discerns and openly rejects potentially violent references and rhythms within public spaces and those involved are taken to task and exposed for what they are. In this way, Missiological Spirit praxis creates an interface between Christian faith and existential realities.

The next section applies these ideas to the 2015 xenophobic attacks as an example in order to demonstrate that the phenomenon of xenophobic violence is exacerbated by public speeches that fire up socio-economic entrenched rage and resentment in black South African grassroots communities.

\section{THE KING'S SPEECH AND 2015 XENOPHOBIC VIOLENCE IN SOUTH AFRICA}

The aim of this section is to concisely demonstrate that inherent in the process of grassroots community violence spiralling in 2015 into xenophobia in South Africa was through the King's speech which served as a catalyst. The deadly xenophobic violence that claimed seven lives in April 2015 is believed to have had its source in the King of the Zulus4 of KwaZuluNatal, Goodwill Zwelithini who was allegedly heard making comments that held intimations of hatred against African foreign nationals living in South Africa. In his public speech which was spoken in the Zulu language 5 in Pongola, northern KwaZulu-Natal, the King stated that:

[W] talk of people [South Africans] who do not want to listen, who do not want to work, who are thieves, child rapists and house breakers.... When foreigners look at them, they will say let us exploit the nation of idiots. As I speak you find their unsightly goods hanging all over our shops, they dirty our streets. We cannot even recognise which shop is which, there are foreigners

\footnotetext{
$4 \quad$ The Zulu people are one of the dominant ethnic groups in South Africa.

5 This translation is affirmed by different organisations (see also City Press 2015; Eye Witness News 2015; De Vos 2015).
} 
everywhere. I know it is hard for other politicians to challenge this because they are after their votes. Please forgive me but this is my responsibility, I must talk, I cannot wait for five years to say this. As king of the Zulu nation ... I will not keep quiet when our country is led by people who have no opinion. It is time to say something. I ask our government to help us to fix our own problems, help us find our own solutions. We ask foreign nationals to pack their belongings and go back to their countries (Times Live 2015).

I am not trying to prove whether these remarks can be classified as hate speech as defined in the Equality Act of the Constitution of South Africa. But Pierre De Vos (2015), an eminent South African constitutional law scholar, has demonstrated from a Constitutional Law perspective that looking at "the context within which the words were uttered it is difficult to avoid the conclusion that the king would be found guilty of hate speech if charged". In his speech, the King diagnosed the problem in contemporary South Africa as twofold: laziness among locals and foreigners dirtying the streets. He then proposed a remedy involving "foreign nationals (legally or illegal) [having] to pack their belongings and go back to their own countries". But the King does not suggest how the deportation of foreigners will cure the perceived pathological laziness. What these remarks seem to demonstrate is an entrenched xenophobia in the language of the king to such an extent that he puts words in the mouths of the foreigners: "they [foreigners] will say let us exploit the nation of idiots." President Jacob Zuma's eldest son, Edward Zuma, supported the King's remarks, stressing that "we [South Africans] need to be aware that as a country we are sitting on a ticking time bomb of them [foreigners] taking over the country" (City Press 2015).

This narrative exposes the insecurity of some leaders in South Africa in a similar way that the narrative of Exodus 1:8-2:10 did to Egyptian leaders. Some black South Africans have quickly forgotten the contribution of other African countries to their liberation. This is a kind of historical experience repeated as in Exodus the Egyptians did not recognise the past contribution of Joseph and Israelites to the socio-political and economic development of Egypt. The Egyptians' political objectives were narrow and nationalistic which influenced their perception of Israel as the enemy (Hewitt 2015). Similar to King Zwelithini's remarks, Pharaoh "said to his people, 'Look, the Israelite people are more numerous and more powerful than we. Come, let us deal shrewdly with them, or they will increase and, in the event of war, join our enemies and fight against us and escape from the land'" (Exodus 1:9-10). He used a vulnerable group of migrants as a scapegoat to cover his leadership inadequacies.

Some people believe that the King's statement may well be blamed for the recent xenophobic attacks that erupted in South Africa. On the obverse side of the coin, the King argued that the remarks made in the Zulu language were misinterpreted, claiming that he only called for the repatriation of illegal immigrants. He argued that the media chose "to deliberately distort what was an innocent outcry against crime and destruction of property" (City Press 2015). He further argued that if he had given orders to kill foreign nationals "this country [South Africa] would be reduced to ashes" (TheGuardian 2015).ThisstanceisdefendedbyPrinceMangosuthi Buthelezi, a politician and Zulu tribal leader who founded the Inkatha Freedom Party (IFP). He argued that "regardless of how one interprets what his majesty said, one thing is clear. He never decreed violence, mayhem, looting, murder or arson" (The Guardian 2015). Yet the King's audience in Pongola who were Zulu seem to have interpreted the king's remarks as decreeing "violence, mayhem, looting, murder or arson". Public speeches are considered one of the most powerful ways of initiating and reinforcing new thinking, feeling and behaviour in the citizens (Baden 2014; Timmermann 2005; Yanagizawa-Drott 2014).

The Socio-economic Rights and Accountability Project (SERAP) (cited in City Press 2015) argues that the statement by the king cannot be justified under any law. It is classified as "hate speech" which "generated fear and hatred that created the conditions for violence and discrimination against Nigerians and other African citizens". SERAP (cited in City Press 2015) further stresses that too often crimes against humanity are followed by speeches like the King's, for "once the climate of violence has been created, direct and public incitement to crimes builds on it, exacerbating the situation by further heating up passions and directing South Africans' hatred towards" African foreign nationals. In an interview, the Witwatersrand University researcher, Jean-Pierre Misago (cited in Eye Witness News 2015) contends that such a statement cannot be easily quoted out of context or be lost in translation as defended. He stresses that the issue of xenophobia is complex because "even people high up in the government share the same feelings as people in the street and when those pronouncements come from the political and country leaders, people on the ground take them as a directive".

King Zwelithini's public speech emerged in the context of political frustration and dissatisfactions, elements rendering his audience (which represents a grassroots majority) vulnerable to his remarks. Current studies on the pathway to genocide have demonstrated how remarks such as the one from the king are poisonous on the minds of a socio-economically and politically frustrated population (Mann 2005; Verwimp 2003; Andre \& Platteau 1998; Longman 1995). Any public speech with socio-economic implications when directed against any particular group of people can be construed as calling for economic reversal through the mechanism of public violence. The growing frustrations of some black South Africans living in poverty, witnessing economic exploitation and leadership crisis have created a volatile atmosphere where any form of public speech can easily be misconstrued as a directive for engaging in public violence. In most cases it is not what is said that matters but who says it, the way it is said, to whom it is said and against whom it directed. During Adolf Hitler's Nazi fascism regime anti-Semitic speeches found fertile ground because of repressed feelings of socio-economic frustrations and fear of weakness among the male population in Germany (Morrock 2010).

The foregoing discussion shows that xenophobia in South Africa is a Missiological challenge as it is not only perpetuated 
by those outside the Church but those in the Church as well. As a comparative analysis of the link between poisonous public speeches and violent conflicts, it unfortunately reveals that the 2015 xenophobic attacks in South Africa were neither inevitable nor mysterious, but rather a phenomenon that is all too common in many sectors of post-apartheid South Africa which manifests in the daily language of ordinary black South Africans but does not translate into violent attacks because those who make remarks are not in a position of political authority to influence a large number of people at once. It is also important to stress that some of these perpetrators may belong to Christian communities. The question can be restated: How can a Missiological Spirit framework enable the Church in South Africa to reconceptualise the message of the kingdom of God and Eucharist encounter as liminary tools for prophetic witness to xenophobia in South Africa?

\section{AT THE THRESHOLD OF THE KINGDOM OF GOD: TOWARDS AN ANTI-XENOPHOBIC MISSIO- THEOLOGY}

If churches in South Africa had prepared their members for the possibility of the king's poisonous public speech that fomented xenophobia, would it have made a difference? It is difficult to predict. What appears clear is that the aftermath of these xenophobic violence unveiled how the Church in South Africa is "largely adjusted to the status quo, standing as a taillight behind other community agencies rather than a headlight leading [humanity] to higher levels of justice" (King 1963). In the aftermath of the tragedies of xenophobia, the Church in South Africa has always tried to make some noise of protest, write the so-called prophetic statements and try to join in the march against xenophobia but no sooner does some calmness manifest than the Church quickly readjusts back to status quo until there is another eruption of xenophobic violence or some other national tragedy. Has the Church in South Africa ever taken an initiative to organise its own peace march protest against xenophobia (or at least the Marikana massacre or any other episode of exteme violence)? Has the Church in South Africa become specialist in responding to human tragedies rather than to life by creating a secure environment for life to flourish without fear of sudden destruction? The aim of this section is to show some ways in which the Church in South Africa can engage in a focussed struggle to create a secure environment for life which can resist xenophobia at least among its members who must bear witness to violence within their homes and societies. In the following I suggest an approach at two levels: at the theoretical as the message of the kingdom of God (hereafter, the kingdom) and at praxis as a Eucharistic encounter.

\subsection{The Kingdom as an anti-violence liminality message}

Scholars have argued that the public message Jesus preached in the New Testament could be summarised in the phrase "the kingdom of God" (Sanders 1985; Dunn 2003; Pitre 2009). The kingdom implies the reign of God in the hearts of those who have accepted Jesus as Lord and Saviour (Roman 10:9).
The proclamation of the kingdom in the teaching of Jesus is unquestionable - it was the mission and the aim of his earthly incarnation (Jeremias 1971; Perrin 1967; van Eck 2009). The kingdom was not a futuristic reality but intrinsically an ethical-eschatological reality rapturously present within the hearts of the believers (Allison 1998). It was proclaimed as a reality in the here and now forming within the disciples a transformed lifestyle "that challenged the kingdoms of this world" (Borg 2006: 186). The kingdom as was proclaimed by Jesus challenged religio-political oppression, inequality, social and economic exploitation which were classified as violence (Moxnes 2003). The tension in the description of the kingdom by Jesus suggests its liminal status - it is here and not yet, is now and still coming. The liminality description of the kingdom permeates the Gospels. For instance, it "has come" (Mt12:28; Lk 11:20), it is "within you" (Lk 17:20-21), it is "at hand" (Mt 10:7; Mk 1:15), "will come" (Mk 9:1) and "is not of this world" (John 18:36). Thus, we cannot fully understand the kingdom of God without appealing to the notion of cultural liminality which could enable us to articulate how the message of the kingdom functions in the world.

The notion of cultural liminality was resuscitated by British Anthropologist Victor Turner (1967, 1969)6 in middle 1950s in the works of Arnold van Gennep. In his renowned book, The rites of passage, van Gennep (1960/1908) outlined a threefold mnemonic phase which defines the rite of passage. Van Gennep noted that during the process of rites, liminal subjects went through a transition period which always begins with separation from general social spaces, enter into the liminal spaces (the heart of the ritual) and then at the end of the ritual be reintegrated into ordinary societies. The community of believers go through a similar threefold mnemonic process as they are separated from the social normative, enter into the church (liminal) space to hear the message of the kingdom of God, re-enact the death of Jesus through the Eucharistic encounter, form a distinctive social bond and re-enter normal socialspacestolive out the message of thekingdom. Intheliminal spaces, participants are regarded as "neither here nor there; they are betwixt and between the positions assigned and arrayed by law, custom, convention, and ceremonial" (Turner 1969:95). Turner (1969:95) writes that "their ambiguous and indeterminate attributes are expressed by a rich variety of symbols in the many societies that ritualize social and cultural transitions". It is the stage of being between phases. The kingdom that Jesus proclaimed places the participants between phases as kingdom (liminal) entities when they enter into church spaces and can be considered as neither in nor outside the kingdom and are neither in nor outside ordinary social spaces - they are betwixt and between them. In this space, they become neither sinners nor righteous but both sinners and righteous, experiencing both hatred and love and both violence and non-violence. This is the ambiguity the faith communities are meant to experience whenever they are in their anti-structural (churches) periods. They are all to be treated equally as pure spirits or holistic beings with no hierarchy and only receive the instructions of Jesus as their liminal guardian. I am aware that the reality in

$6 \quad$ Victor Turner discusses in detail the meaning of liminality using empirical evidence from the Ndembu people of Zambia. 
contemporary Church is downright dissimilar. Yet this does not keep me from trying to show that liminal experiences should be part of the Christian experience of the presence of the Spirit in their churches. The significance of these experiences partly depends on their difference from social normative realities that define daily life in the ordinary social order. Regrettably, the Church appears to be structured radically after the social order of ordinary societies. Jesus proclaimed the message of the kingdom in unstructured spaces so that liminal participants who were his disciples could be urged to develop an intense and radical solidarity and egalitarian lifestyle in which the normative distinctions of rank and status, power and privilege, gender and role, law and institution no longer determined their social relations. The only thing they were subjected to was the teaching of the kingdom espoused by Jesus Christ. Some of the disciples who aspired to become greater than their fellow disciples, he commanded to become lesser citizens or servants. For Jesus the leadership model of the disciples was supposed to diverge from the political and religious model leadership that prevailed at the time when those in authority were lords and benefactors (Lk 22:22-27). This means that even in the cases where they were struggling, for example, to radically accept one another as equal beyond ethnicity, gender or race, it was imperative that visible commitment be demonstrated in word and deed. Johan Cilliers (2009:25, 2013:1) notes that the "liminal experience is filled with potential and creativity, but also with risk and danger".

The new model of relationship that Jesus envisaged to emerge among liminal participants in message of the kingdom is what Turner (1969:96) calls a communitas (distinguished from community) - "as unstructured or rudimentarily structured and relatively undifferentiated...communion of equal individuals". Even now the struggle of every liminal participant should be to become like the Anthropos Jesus -the acquisition of the humanness of Jesus perceived as always becoming (1 Cor. 11:1; 2 Cor. 3:17-18, 5:17; Eph. 4:22-24, 5:1-2). Rethinking the message of the kingdom as a liminal message has the potential for the formation of the believers' social bond and conscientization against xenophobia embedded in public speeches and individual remarks in contemporary South Africa. It is an alternative way of prophetically resisting xenophobia within the communities of faith as the members of the Christian communities are not immune to the perpetration of xenophobia.

The kingdom of God as a liminal space for formation of communitas implies that Jesus inaugurated an alternative social order to secure human worth and dignity which cannot be achieved through the state. It is unfortunately true that some clergy members in South Africa think that when they are helping victims of xenophobia they are "...assisting government" (Pastor Dennis, Rosebank Union Church cited in Phakathi 2010:2, italics as found). If there is any lesson that the history of politics in South Africa since independence has taught us, it is that socio-economic transformation will never be achieved by the powers of the state. The failing economies and leadership crises are "signs of the time" pointing to the fact that the Church must awaken and become an alternative story in South Africa. The state's failure is evident in that the liberationist, reformist and revolutionary governments have not made any difference in rescuing the country from the abyss of socio-material disgrace of the masses for the past over two decades since independence. Where do we turn? What is the Church doing about this? We have to reclaim the message of the kingdom as a liminality message and begin to invade public spheres with peaceful and non-violence lifestyle. The kingdom of God contains the teleology of Christian thought. It translates theology from static, abstract reflection into dynamic Missiological Spirit praxis in which the Word becomes flesh - concreteness of Jesus in human experiences (John 1:14). Jesus always becomes concrete in the context of violence, negativity and contradiction. It is always an error to separate Jesus from human suffering and violence because it is within this realm of struggle for authenticity, for jobs, for equality and justice that Jesus becomes concrete as that "Word" continuously becomes flesh.

The kingdom was the messianic socio-political and economic manifesto (Hendricks 2011). Obery Hendricks (2011:123) contends that;

Jesus' vision of the kingdom of God includes an egalitarian socio-economic order that takes responsibility for the wellbeing of all. It refuses to be hindered from the task of serving the needs of the dispossessed and vulnerable by official sanctions, traditional narratives of social control or even by edicts from on high, if they stand in the way of the kingdom's goal of ensuring that the basic elements of a healthy and secure life are available to all.

The kingdom of God remains messianic strategy for fighting systemic injustice and violence; for reconciliation of the estranged; for humanisation of the dehumanised; for humanisation of public spheres and public speech; for humanisation of social, religious, political and economic life of the nation; and empowering the masses to engage in their own socio-economic transformation. The strategy of implementation did not necessarily base itself on discerning where the kingdom worked in the world as it was "within" the disciples (Luke 17:21). According to Jesus, the kingdom manifests itself wherever demons are exorcised, people are healed and the hungry are fed. The demons stand for destruction and violence against humanity and God's creation. Those who have received the kingdom received the power of the Holy Spirit to cast out demons as a demonstration of the kingdom. They were admonished to express the kingdom values of righteousness, peace and joy (Romans 14:17) in their fractured world. The kingdom is only expressive and relevant because of the brokenness, the wounded-ness, fractured-ness, polarisedness, leadership crises, economic mishaps, political upheavals and the essential failure of human governance. It is the rapture of the inner revolt or revolutionary consciousness or critical consciousness to "love" the "neighbours" unconditionally as self (Matthew 22:39). In other words, the kingdom, as was demonstrated through the incarnation and the public ministry of Jesus Christ, envisages social transformation not necessarily as a process of activism but rather as a by-product of the disciples' daily expression of the values of the kingdom in their own lives by resisting conformity to the standards of this world (Rom 12:1-2). Therefore, a critical understanding of the non- 
violence implications of the kingdom in contemporary South Africa is critical in dispelling the tyrannical public speeches because it urges values such as peace, justice, love, equality and so on to become the measure of all that emerges from the public speeches. The Missiological Spirit does not call on Christians to withdraw into a religious ghetto of rejection of all that comes from the public spaces but calls the Church to be a watchdog, a gatekeeper, a watcher on the walls of nonviolence as it sounds the alarm to raise critical awareness to its members so that they are able to independently "test them all; hold on to what is good" (1 Thessalonians 5:21).

To have the kingdom of God within them meant to have the autonomous rational power to negotiate the systems of this world and any toxic dominant speech that functioned against the kingdom principles. There is no possibility that people can obey the principles of the kingdom and at the same time turn cold-shoulder to or kill their neighbour. To accept the message of the kingdom is not only about intellectually apprehending its principles but about engaging in a lifelong struggle against conformity to the corruption of the dominant political narrative by internalising and becoming one with kingdom values - inculcating them in the human heart. The lordship or kingship of Jesus is realised or actualised wherever the values of the kingdom become concrete as lived experiences. Thus, the message of the kingdom cannot be separated from its Eucharistic ritual praxis.

\subsection{The Eucharist as ritual praxis of the message of the Kingdom of God}

The Eucharistic encounter is one of the sacraments that is practised in every branch of the Christian tradition. If this ritual were to be understood as a liminal re-enactment of the death of Jesus and reinforcement of the kingdom message can function as a catharsic space and Missiological conscientization for prophetic witness to human violence, specifically xenophobia, a great advance would have been made. As argued above the Eucharistic encounter happens in a liminal (church) space separated from the normative social order. It is situated in a movement that begins with separation from social structures plagued by daily violence into liminal spaces where believers symbolically experience and re-experience injustice, violence and the death of Jesus in their own lives and thereafter they symbolically experience and re-experience life, rebirth and regenerative renewal which empowers them to re-enter normative society to bear witness to non-violence through lifestyle and actions of resistance to violence. The argument here is that when believers encounter God through the Eucharist, it should be a deliberate means to help them realise that they are also encountering their inner violence and generic violence in their societies. Louis Cameli (2012:91) observes that "although our Eucharistic setting may be tranquil and undisturbed, we know that the Eucharist is a sacrament" wrought through Jesusophobic (hatred of Jesus by religious leaders) violence and death of an innocent human being. It is a ritual of reconciliation for estranged human beings. This is a table on which worshippers who come with hearts filled with (xenophobic) violence and wounds can symbolically pour them on Jesus who alone can absorb the sting and destruction through his broken body. Kevin Kelly (2005:25) argues that the remembrance "in [the] Eucharist is keeping alive the memory of a bloody and cruel act of violence...commits the Christian Church and every Christian to never forgetting a horrendous act of violence against the person of the one whom they believe to be the Son of God". This re-enactment of remembered human violence is a form of catharsis that is meant to enable Eucharistic participants to vent their inner rage, anger and violence unto the One who has borne human pain, injustice and violence.

The foregoing shows that the rite of the Eucharist is essentially the rite of passage from violence and estrangement to reconciliation, unconditional acceptance and unconditional love. Those who have participated in the Eucharist have the right to know the implication of participating in the ritual that epitomises human violence and injustice and how these have resulted in a fundamental alienation within individual human beings from themselves, others, creation and God and the destruction of the world. In participating in the Eucharist, believers are called upon to re-enact their individual and general contribution to injustice, xenophobia and generic violence that are taking daily toll on human life in South Africa. It confronts believers with the realities of deep wounds, political betrayal and divisions of human struggles. It presents the enduring violence and injustice in South Africa which is a source of distress, poverty, ecological crisis, HIV and AIDS, gender injustice and inequality, rape, religious violence, ethnicity, racism, ethnocentrism, leadership crisis, greediness, xenophobia, corruption, capitalism, consumerism and many other life-destroying forces, all bearing witness to the devastating effects of human violence. The Eucharistic liminal encounter with Jesus, the violence-bearer, the Prince of peace and ultimate reconciler, has the potential to empower believers to make fresh commitments and declarations each time they leave the liminal space to work with the Spirit of life for the full liberation of human consciousness from violence. The continuous separation from normative society and reenactment of violence through the Eucharist and constant reincorporation into general society means that Eucharistic participants can be relentlessly and consistently exhorted, reminded, re-empowered, re-inspired and reinvigorated to struggle over and over again to develop a lifestyle of nonviolence by implementing non-violent behaviour in their own lives, families, communities and in all walks of life. The communitas - the bond of trust and interrelatedness formed as a result of incessant encountering and re-encountering one another as the kingdom is proclaimed and through the liminal reign of the Eucharist - also means that the worshippers are accountable and have responsibility to challenge one another to radical peace and a non-violent lifestyle (Ephesians 4:15-16; Colossians 3:9-10).

\section{CONCLUSION}

This article intended to demonstrate that the kingdom of God suggests critical and revolutionary thinking and doing activities that are not determined or shaped by the human government or the state. It is an alternative way to live in solidarity and cooperation with grassroots communities. The key for human 
emancipation from the tyrant embodied in public speech and its envisioned violent conflict is not simply prophetic speaking to the powers that be, but a prophetic engagement in living lifestyles that critique normative society. Any attempt to change society involves doing, activity, creating new ways of being in the world, new possibilities for socio-economic transformation and ultimately have the real potential of finding a remedy to the persistent social ill expressed in this context through the horrific and destructive phenomenon of xenophobia.

\section{BIBLIOGRAPHY}

A New WCC Affirmation on Mission and Evangelism, 2012. Together towards Life: Mission and Evangelism in Changing Landscapes. International Review of Mission, 101/2: 250-280.

Allison, D.C. 1998. Jesus of Nazareth: Millenarian Prophet. Minneapolis: Fortress.

André, Catherine \& J-P Platteau. 1998. Land relations under unbearable stress: Rwanda caught in the Malthusian trap. Journal of Economic Behavior \& Organization, 34/1: 1-47.

Baden, C. 2014. Constructions of Violent Conflict in Public Speech: Conceptual Framework for the Content \& Speech Analytic Perspective (Within WP5, WP6, WP7, \& WP8), INFOCORE Working Paper, www.infocore.eu/results/ [accessed 26 April 2015].

Baker, A. 2015. Brutal Murder Is Sparked by Anti-Immigrant Rage in South Africa, http://time.com/3828398/xenophobia-south-africa/. [Accessed 14 Aug. 15.]

Borg, M.J. 2006. Jesus: Uncovering the life, teachings, and relevance of a religious revolutionary. New York: Harper-Collins.

Bosch, D.J. 1991. Transforming mission: Paradigm Shifts in Theology of Mission, $20^{\text {th }}$ Anniversary edition. New York: Orbis.

Cameli, Louis J. 2012. Bread of Life: Exploring the Presence of Eucharist in Our Lives. Chicago: Liturgy Training Publications.

Cilliers, J.H. 2009. Worshipping in the 'in-between' Times of Transition: Reflections on the Liminality of Liturgy. In Pieterse H \& C Thesnaar (eds.). A Faithful Witness: Essays in Honour of Malan Nel. Wellington: Bybel Media, 167-179.

Cilliers, J.H. 2013. Between Fragments and Fullness: Worshipping in the in-between Spaces of Africa. HTS Teologiese Studies/Theological Studies, 69/2:1-6.

City Press, 2015. King Zwelithini's 'xenophobic' remarks 'lost in translation, http://www.citypress.co.za/news/king-zwelithinis-xenophobic-remarks-lost-in-translation/. [Accessed 29 April 2015].

City Press, 2015. Xenophobia: ICC gets hate-speech complaint against King Zwelithini, http://www.citypress.co.za/news/xenophobia-icc-gets-hatespeech-complaint-against-king-zwelithini/. [Accessed 29 April 2015].

De Vos, P. 2015. Xenophobic statement: Is King Zwelithini guilty of hate speech? http://constitutionallyspeaking.co.za/xenophobic-statement-is-king zwelithini-guilty-of-hate-speech/. [Accessed 29 April 2015].

Dunn, J.D.G. 2003. Christianity Making. Vol1: Jesus Remembered. Grand Rapids, MI: Eerdmans.

Eye Witness News. 2015. Zulu King Faces More Criticism over Controversial Comments, http://ewn.co.za/2015/04/16/Zulu-Kings-comments-taken-totask. [Accessed 29 April 2015].

Hendricks, O.M. 2011. The Universe Bends Toward Justice: Radical Reflections on the Church, the Bible, and the Body Politic. Maryknoll: Orbis Books.

Hewitt, R.R. 2015. From welcomed migrants to alleged terrorists: A missio-political reading of Exodus 1:8-2:10, Stellenbosch Theological Journal, 1/2: 447-470, DOI: http://dx.doi.org/10.17570/stj.2015.v1n2.a21. [Accessed 14 June 2015].

Jeremias, J. 1971. New Testament Theology: The Proclamation of Jesus, trans. John Bowden. London: SCM.

Kelly, K. 2005. Eucharist and Violence. The Furrow, 56/1: 25-36.

Keum, J. ed. 2013. Together toward Life: Mission and Evangelism in Changing Landscapes. Geneva: World Council of Churches Publications.

King, M.L. Jr. 1963. Letter from the Birmingham Jail, http://www.stanford.edu/ group/King/Docs/birmingham.html. [Accessed 14 Aug. 15.]

Kirk, J.A. 2000. What is Mission? London: Darton, Longman \& Todd.

Longman, T. 1995. Genocide and Socio-Political Change: Massacres in Two Rwandan Villages. Issue: A Journal of Opinion, 23/2:18-21.

Mann, M. 2005. The Dark Side of Democracy. Cambridge: Cambridge University Press.

Moltmann, J. 1992. The Spirit of Life: A Universal Affirmation, trans. Margaret Kohl. London: SCM Press.

Morrock, R. 2010. The psychology of genocide and violent oppression: a study of mass cruelty from Nazi Germany to Rwanda. London: McFarland \& Company, Inc.

Moxnes, H. 2003. Putting Jesus in his place: A radical vision of household and king dom. Louisville, KY: Westminster John Knox Press.

Ndlovu-Gatsheni, S.J. 2012. Beyond the Equator There Are No Sins: Coloniality and Violence in Africa. Journal of Developing Societies, 28/4: 419-440.

Perrin, N. 1967. Rediscovering the Teaching of Jesus. New York: Harper \& Row.

Peters, T. 2000. God - The World's Future: Systematic Theology for a New Era. Minneapolis: Fortress Press.

Phakathi, S. 2010. The response of Churches to the May 2008 xenophobic violence, http://www.atlanticphilanthropies.org/app/uploads/2010/07/11_ Church c.pdf. [Accessed 14 Aug. 15.]

Pitre, B. 2009. Jesus, the Messianic Banquet, and the Kingdom of God, Letter \& Spirit 5:145-166.

Sanders, E.P. 1985. Jesus and Judaism. Philadelphia: Fortress.

Squires, Catherine R. 2002. Rethinking the Black Public Sphere: An Alternative Vocabulary for Multiple Public Spheres. Communication Theory, 12/4: 446-468.

The Guardian, 2015. Zulu leader suggests media to blame for South Africa's xenophobic violence, http://www.theguardian.com/world/2015/apr/20/ south-africa-xenophobic-violence-zulu-king-goodwill-zwelithini. [Accessed 29 April 2015].

Times Live, 2015. Listen to exactly what King Goodwill Zwelithini said about foreigners, http://www.timeslive.co.za/local/2015/04/16/listen-to-exactlywhat-king-goodwill-zwelithini-said-about-foreigners. [Accessed 29 April 2015].

Timmermann, W.K. 2005. The Relationship between Hate Propaganda and Incitement to Genocide: A New Trend in International Law towards Criminalization of Hate Propaganda? Leiden Journal of International Law, 18: 257-282.

Townsley, J. 2003. Rene Girard's Theory of Violence, Religion and the Scapegoat, www.jeramyt.org/papers/girard.html [accessed 14 August 2015].

Turner, V.W. 1967. The Forest of Symbols: Aspects of Ndembu ritual. Ithaca, N.Y.: Cornell University Press. 
Turner, V.W. 1969. The Ritual Process: Structure and Anti-structure. Ithaca, N.Y.: Cornell University Press.

Van Eck, E. 2009. A Prophet of Old: Jesus the Public Theologian. HTS Teologiese Studies/Theological Studies, 66/1: 1-10.

Van Gennep, A. 1960/1908. The Rites of Passage. Chicago: University of Chicago Press.

Verwimp, P. 2003. An economic profile of peasant perpetrators of genocide: Micro-level evidence from Rwanda. Journal of Development Economics, 77/2: 297-323.

Yanagizawa-Drott, D. 2014. Propaganda and conflict: Evidence from the Rwandan genocide. The Quarterly Journal of Economics, 129/4: 1947-1994.

Yong, A. 2014. The Missiological Spirit: Christian Mission Theology in the Third Millennium Global Context. Eugene, Ore.: Cascade Books.

Žižek, S. 2009. Violence: Six sideways reflections. London: Profile Books. 